\title{
The Influence of Limits to Growth and Global 2000 on U.S. Environmental Governance
}

\author{
Michael Lerner ${ }^{1}$, Ryo Fujikura ${ }^{2}$, Mikiyasu Nakayama ${ }^{3}$ \& Manami Fujikura ${ }^{4}$ \\ ${ }^{1}$ Environmental Law Institute, Washington, D.C., United States of America. \\ ${ }^{2}$ Faculty of Sustainability Studies, Hosei University, Tokyo, Japan. \\ ${ }^{3}$ Graduate School of Frontier Sciences, The University of Tokyo, Chiba, Japan. \\ ${ }^{4}$ J. F. Oberlin University, Tokyo, Japan. \\ Correspondence: Ryo Fujikura, Faculty of Sustainability Studies, Hosei University, Chiyodaku, Tokyo, $102-8160$ Japan.
}

Received: June 13, 2016

doi:10.11114/ijsss.v4i8.1674

\author{
Accepted: June 27, 2016 \\ Available online: June 30, 2016 \\ URL: http://dx.doi.org/10.11114/ijsss.v4i8.1674
}

\begin{abstract}
This paper assesses the influence of two reports, "The Limits to Growth" and "The Global 2000 Report to the President-Entering the Twenty-First Century," on environmental governance in the United States. Published in 1972 and 1980, respectively, both reports used different methodologies to project changes to the global environment, but reached similar conclusions: business-as-usual economic growth was unsustainable and would lead to the collapse Earth's life-support systems in the 21 st century. Relying on eight oral interviews conducted with experienced and influential persons from environmental NGOs, academia, and the U.S. government, supplemented by a systematic literature review, this analysis finds Limits and Global 2000 had a limited influence on U.S. environmental governance. The reports contributed to greater awareness of the need for sustainable growth, especially among environmentalists, the U.S. government, and the business community; introduced system dynamics and computer modeling to the environmental policymaking process; and directly catalyzed some policy development, particularly in the context of international environmental negotiations. Despite these achievements, Limits and Global 2000 could not catalyze movement toward sustainable development at sufficient scale. The reports' recommendations were rebuffed by the hostile political agenda of the Reagan Administration, their proponents frustrated by policymaking tools ill-suited to long-term system-level decisionmaking, and their message subsumed by the drive for short-term economic growth. The reports' projections remain largely valid, but decisionmakers have long dismissed them as irrelevant.
\end{abstract}

Keywords: The Limits to Growth, the Global 2000 Report, Environmental Governance, United States, Projection.

\section{Introduction}

The Limits to Growth ("Limits") and The Global 2000 Report to the President-Entering the Twenty-First Century ("Global 2000") are widely regarded as two of the most important and influential reports of the modern environmental movement. In the years since their publications in 1972 and 1980, respectively, the reports have been the subject of multiple retrospective analyses and high-level conferences (e.g. Pirages and Cousins 2005; Turner 2008 ; the 2012 "Perspectives on Limits to Growth: Challenges to Building a Sustainable Planet" conference at the Smithsonian Institution). Yet, these analyses focus exclusively on the contents of the reports and their accuracy, leaving unaddressed the nature of the reports' impact on environmental governance. This paper fills that gap by investigating the character and extent to which Limits and Global 2000 influenced decisionmaking on environmental governance in the United States.

After a brief methodological section, the paper presents a brief summary of the production, contents, and initial reception to Limits and Global 2000. The next section examines how the reports built awareness of the global character of environmental problems and the potential consequences of disrupting global life-support systems, inspiring leaders in government, civil society, and industry to incorporate sustainable development into their decisionmaking. The following section considers the factors that hindered the reports from catalyzing the social, economic, and political changes necessary to create a sustainable society. The paper concludes with an assessment of the continuing relevance and vitality of the issues discussed in Limits and Global 2000, as well as some lessons for future efforts to achieve 
sustainability before the collapse of Earth's life-support systems.

\section{Method}

Since few decisionmaking documents cite Limits or Global 2000 explicitly, this analysis relies principally on eight oral interviews conducted between December 2015 and February 2016 with current or former leaders from across the environmental community. Interviewees are listed in Table 1. Four additional people, three former government officials and one from civil society, were invited to participate, but did not agree to be interviewed. The interviewees represent a broad range of decisionmakers and thought leaders from environmental civil society organizations, academic institutions, and the executive and legislative branches of the U.S. government. The interviews lasted between approximately 30 and 90 minutes and consisted of a set combination of open-ended and targeted questions.

The interviews were supplemented by a systematic literature review of a broad range of sources, including academic analysis, recorded speeches, retrospective memoirs, and primary source material from the Congressional Record and presidential archives.

Table 1. List of Interviews

\begin{tabular}{|c|c|}
\hline Name & Relevant affiliation(s) \\
\hline \multirow{3}{*}{ John C. Dernbach } & $\begin{array}{l}\text { Distinguished Professor of Law, Director, Environmental Law and Sustainability } \\
\text { Center }\end{array}$ \\
\hline & Widener University Commonwealth Law School (1993-Present) \\
\hline & $\begin{array}{l}\text { Director, Office of Policy, Pennsylvania Department of Environmental Resources } \\
(2003-2005)\end{array}$ \\
\hline William M. Eichbaum & $\begin{array}{l}\text { Senior Fellow and Vice President, World Wildlife Fund (1989-Present) [various } \\
\text { programs] }\end{array}$ \\
\hline Richard Frandsen & $\begin{array}{l}\text { Counsel, Energy and Commerce Committee, U.S. House of Representatives } \\
(1977-2009)\end{array}$ \\
\hline \multirow{3}{*}{ Denis Hayes } & President and CEO, Bullitt Foundation (1992-Present) \\
\hline & Founder and Board Chair, the Earth Day Network (1970-Present) \\
\hline & Director, Solar Energy Research Laboratory (1979-1981) \\
\hline William H. Meadows & President, The Wilderness Society (1996-2012) \\
\hline \multirow{3}{*}{ Jonathan Lash } & President, Hampshire College (2011-Present) \\
\hline & President, World Resources Institute (1993-2011) \\
\hline & Co-Chair, President's Council on Sustainable Development (1993-1999) \\
\hline \multirow[t]{2}{*}{ James W. Moorman } & $\begin{array}{l}\text { Assistant Attorney General, Land \& Natural Resources Division, U.S. Department } \\
\text { of Justice (1977-1981) }\end{array}$ \\
\hline & Executive Director, Sierra Club Legal Defense Fund (1971-1976) \\
\hline \multirow{6}{*}{ James Gustave Speth } & Professor of Law, Vermont Law School (2009-2015); \\
\hline & Dean, Yale School of Forestry and Environmental Studies (1999-2009) \\
\hline & Administrator, United Nations Development Programme (1993-1999) \\
\hline & Founder and President, World Resources Institute (1982-1993) \\
\hline & Member and Chair, Council on Environmental Quality (1977-1981) \\
\hline & Co-founder and Staff Member, Natural Resources Defense Council (1970-1977) \\
\hline
\end{tabular}

(Source) Authors

\section{Limits and Global 2000: Different Methods, Similar Conclusions}

Over the course of the 1970s, two concerns spread among the intellectual leaders of the U.S. environmental movement. First, it was increasingly clear that many environmental problems could only be addressed through global action (W. H. Meadows, 2015). Having focused largely on domestic pollution control up to that point, the U.S. environmental 
movement risked creating a "fool's paradise" by allowing environmental problems to fester in the rest of the world (Speth, 2016). Second, environmentalists were dissatisfied with the use of Gross Domestic Product (GDP) to assess a society's development. They believed GDP provided an overly simplistic perspective, measuring only the quantity of development without capturing its quality, neglecting concerns like social equity and environmental habitability (Speth, 2014, p. 136). GDP also ignored the "fundamental incompatibility between limitless growth and an increasingly small and limited planet" (Speth, 2014, p. 137). As these concerns coalesced, "a sense of planetary limits was palpable" (Speth, 2014, p. 137).

Building upon the environmental movement's desire for a broader, more nuanced understanding of the implications of development, Limits and Global 2000 represent two of the most rigorous attempts to consider how the economy can be made to work within the ecological and resource boundaries of the planet over the long term (Dernbach, 2015). However, although Limits and Global 2000 ask similar questions, the reports came about in different contexts, through different processes, and using different methods (Speth, 2016).

\subsection{The Limits to Growth}

Limits is the first study to combine system dynamics and computer modeling (Kress, 2012), combining long-term global data to construct five aggregate variables describing population, food production, industrial output, persistent pollution, and consumption of non-renewable natural resources (D. H. Meadows, Meadows, Randers, \& Behrens III, 1972, p. 25). The researchers created a feedback-rich computer model ("World 3") and simulated how the five variables would interact well into the $21^{\text {st }}$ century in twelve scenarios (Barney, 2002, p. 128). Four of the scenarios show sustainable outcomes and eight outcomes where the global system overshoots and leads to collapse. The "business-as-usual" case is among the latter, demonstrating, "prevailing growth policies will lead to overshoot and collapse, not [an] asymptotic approach to limits" (D. L. Meadows, 2012). Nevertheless, the researchers repeatedly point out that the scenarios were projections, not predictions, noting, "if we [can] change some policies, not only technical policies, but social and cultural policies, then a different future is plausible" (D. L. Meadows, 2012).

Limits received substantial public attention soon after its publication, in large part due to the title's provocative assumption of limits to growth (Dernbach, 2015; Eichbaum, 2015). It attracted scores of news articles, and the report was widely read and discussed in environmental, scientific, and political communities throughout the world (Kress, 2012; Moorman, 2016). The report was a surprise to most people, even knowledgeable members of the environmental community (Hayes, 2016). Written for the Club of Rome, a "high-level but mysterious group," and only vetted in a small peer review before its release, Limits' complex and innovative analysis seemed to come out of nowhere (Hayes, 2016).

The report "did not prove that there are limits to physical growth on a finite planet. [The authors] assumed it" (D. L. Meadows, 2012). However, the impossibility of unlimited growth was far from a generally accepted principle. Newspapers and magazines published negative attacks within days of its release, mostly from economists who called the report, "utter nonsense," and, "simplistic" (Reinhold, 1972; Silk, 1972). They charged the authors of using inadequate data and unjustifiably pessimistic assumptions about human innovation and capacity for adaptation (Nørgård, Peet, \& Ragnarsdóttir, 2010). These attacks inspired articles coming to the report's defense, with one piece quoting William Ruckelshaus, then Administrator of the Environmental Protection Agency (EPA), as saying: "The questions raised by the Club of Rome are what really matter; to attack particular figures is irrelevant" (Lewis, 1972). With the "advantage of being attacked" (Hayes, 2016), combined with the rise of environmental issues in the American political consciousness of the early 1970s more generally, Limits held news coverage for months, became a talking point among many people (Lash, 2016; Moorman, 2016), and went on to sell over twelve million copies.

\subsection{Global 2000}

Global 2000 was initiated by order of President Jimmy Carter in his Environmental Message to Congress of May 23, 1977 (Barney, 2002, p. 124). Convinced of the need to coordinate the government's response to international environmental problems by Charles Warren, then Chairman of the Council on Environmental Quality (CEQ) (Speth, 2014), Carter directed the CEQ and the Department of State to study the "probable changes in the world's population, natural resources, and environment through the end of the century," an effort that would provide, "the foundation of our longer-term planning" (Carter, 1977, sec. 6). The study became a three-year project involving 13 federal agencies, culminating in the release of a three-volume report on July 24, 1980 (Barney, 2002, p. 124; Speth, 2016).

Like Limits, Global 2000 also used computers to develop trend projections using long-term global data, but it used a higher level of detail and more rigorous assumptions (Dernbach, 2015). Instead of agglomerating data into a small set of granular variables, Global 2000 took long-term sectoral models already in use by different government agencies, harmonized their assumptions, and created feedback loops between sectors (Barney, 2002, p. 124). This amalgamated "Global Model" allowed the government to present internally consistent projections of world trends in population, 
resources, and the environment (Barney, 1980, p. v).

Global 2000 was an "insider project" involving dozens of people, and its organizers attempted to build consensus for the report's conclusions across its various constituencies (Hayes, 2016). This collaborative process meant that, even though the report was drafted within six months, the review process took two years (Barney, 2002, p. 124). The unreliable nature of the Government's models contributed to the delay, but it was largely the product of hostile reviewers who would have liked to "emasculate" the study by altering its findings (Barney, 2002, p. 124). The White House public relations staff was particularly concerned that a report pointing to disconcerting trends and global problems would be just another source of bad news for the Carter re-election campaign. This pressure forced the report authors to create fourteen drafts of the summary report, adding an additional nine months of delay (Barney, 2002, p. 124).

Despite the political pressure, Global 2000 remained a "powerful report" (Speth, 2014, p. 138). The report is an early example of the U.S. government considering the sustainability of economic development seriously (Dernbach, 2015), and it is the first and only time any government has created a set of comprehensive, global-scale projections over the long-term (Speth, 2016, p. 201). Although not as explosive as Limits, Global 2000 did eventually sell 1.5 million copies, a considerable quantity for an environmental report (Speth, 2016).

Despite the significant methodological differences between the two reports, nothing in Global 2000 contradicts Limits (Barney, 2002, p. 124; Speth, 2016). Global 2000's conclusions echo those of Limits, with projections that suggest, "if present trends continue, the world in 2000 will be more crowded, more polluted, less stable ecologically, and more vulnerable to disruption than the world we live in now ... life on for most people on earth will be more precarious in 2000 than it is now-unless the nations of the world act decisively to alter current trends" (Barney, 1980, p. 1).

\section{Positive Impacts of the Reports in Environmental Movement}

\subsection{Raising Awareness of the Environmentalists}

Inspired by Limits, Global 2000, and similar reports over the course of the 1970s, many "Teddy Roosevelt-style" environmentalists, traditionally focused on local-level wilderness conservation, began to view environmental problems in a broader context (W. H. Meadows, 2015; Moorman, 2016). As remediation and prevention programs worked to ameliorate most local environmental problems, the environmental movement began to discern more clearly the linkages between local, acute environmental problems and global issues like the pollution of the oceans, water crises, and climate change (Hayes, 2016). This systems-level approach to environmental problems within the environmental community, popularized by serialized publications like the WorldWatch Institute's State of the World books (1984present) and the "World Resources Report" series by the World Resources institute (1986-present) (Speth, 2016), could be described as, "think globally, apply locally, and solve nationally" (Hayes, 2016).

To many environmentalists, Limits stated the obvious: the productive systems of Earth determine the boundary conditions of life (Eichbaum, 2015; Lash, 2016). The report's message was even reassuring for environmentalists like Denis Hayes, who had reached similar conclusions and spoken publically about their convictions without the support of rigorous analysis (Hayes, 2016).

What environmentalists found most exciting about Limits was that it attempted to determine how close society was to exceeding the limits of Earth's life-support systems (Moorman, 2016). In doing so, it provided a frame for the larger issue of sustainable development. Over the following decades, resource conservation and sustainable development have become standard topics of conversation within the environmental community (W. H. Meadows, 2015), and the general public is slowly coming to accept the existence of planetary systems and the need for conservation on a finite planet (Moorman, 2016).

While Limits got the conversation started about sustainable development, Global 2000, through the efforts of the World Resources Institute (WRI), helped power the environmental movement's pivot toward sustainability. After the end of the Carter Administration, Gus Speth, who supervised the creation of Global 2000 as Carter's last CEQ Chairman, created WRI as a vehicle for turning the report's findings into policy outcomes (Lash, 2016). As one of the three main organizations (along with the WorldWatch Institute and the United Nations Environment Programme) to drive sustainability into the U.S. political mind, the creation of WRI may have been the most important outcome of Global 2000 in the U.S. context (Speth, 2016).

\subsection{Building awareness in the U.S. government}

Despite the broad popular appeal of Limits, the report had a mixed reception within the U.S. Government. Although some may have read Limits and been influenced by its message (Moorman, 2016), the report gained little traction among Congressional staff. For example, Richard Frandsen, the lead staffer on the House Energy and Commerce Committee for 25 years, had never heard of Limits until approached for an interview for this article (Frandsen, 2016). 
Similarly, the Executive branch "maintained that it had little or nothing to say about Limits because it had no global study and could not prepare one because it had no global model" (Barney, 2002, p. 124). Nevertheless, although Limits "never figured very prominently" in discussions between Barney and Speth when preparing Global 2000 (Speth, 2016), the report's authors were aware of the Limits models and compared the two studies' models (as well the World Integrated Model, as a revised version of the model used in Limits) in the appendix to the Global 2000 Summary Report (Barney, 1980, p. 45).

In contrast, Global 2000's message captured the attention of policymakers at the highest echelons of government. In his memoir, Angels by the River, Gus Speth recounts his surprise when, toward the end of a speech to several hundred guests in the White House's East Room, Jimmy Carter "proceeded to review, quite eloquently, a number of these threats [described in Global 2000], and concluded on an optimistic note: 'the last decade has demonstrated that we can buck the trends" (Speth, 2014, p. 139). Carter continued to believe in the importance of Global 2000's message, promoting the report even after leaving the White House in 1981 (Shabecoff, 1983).

WRI's engagement with Congress is a key reason Global 2000 was able to make a significant impact in Congress. Despite the report's relatively low profile and technical language, many influential staffers and policymakers read Global 2000, building politicians' awareness of the interdependency of population, resources, and environment. Some Congressmen even referenced Global 2000 by name in committee hearings (Frandsen, 2016). WRI's most significant involvement took the form of its education program for Congressional representatives and their staff. WRI worked successfully with Senators Al Gore, John McCain, Lindsay Graham, and Tim Wirth, among others, to bring concerns about sustainability and long-term environmental trends to the forefront of the American political scene (Speth, 2016). WRI's policy analyses also influenced decisionmakers, especially during the late 1980s and 1990s (Eichbaum, 2015).

In the decades following Limits and Global 2000, WRI's activities helped spread the ideas of limits to growth, the need to reduce the resource intensity of development, and the interconnecting dynamics of the global system (Dernbach, 2015; Eichbaum, 2015). These concepts are reflected in a handful of bills and resolutions that, although none became law, demonstrate at least some members of Congress have long appreciated the need for sustainable development and long-term planning. One such bill was, "A Joint Resolution Calling on the Executive Branch to Conform to the Recommendations of the Global 2000 Report," introduced by Rep. Nicholas Mavroules in 1983. The bill expressed the "sense of the Congress that the executive branch should begin to coordinate and improve its projections and analysis of world population, resources, and environmental trends as outlined in the Global 2000 study" (Mavroules, 1983).

\subsection{Introducing System Dynamics and Computer Modeling}

Limits, and Global 2000 to some extent, helped introduce system dynamics and computer modeling as a means of providing decisionmakers with information about the long-term consequences of proposed policies (Dernbach, 2015). The authors of Limits used the principles of systems dynamics to pioneer "a new technique for integrating for integrating economic, social, technical, environmental, and other areas of knowledge into a coherent theory," and then used computers to develop the first sophisticated model capable of providing long-term projections on a global scale (D. L. Meadows, 2012).

Before the advent of computers, decisionmakers evaluated the prospective consequences of policy decisions through qualitative assessments (Lash 2016). This approach did not rely on complex models, since the computing power to do such calculations was not readily available (Dernbach 2015). Even when quantitative projections were established, estimates were often so imprecise as to undermine the persuasive power of the calculation (Dernbach 2015).

\subsection{Building Awareness in the Business Community}

For much of the twentieth century, most members of the business community did not place much value in environmental protection. When confronted with evidence of their polluting activities, corporate executives often chose to ignore or refute it. Consequently, the modern environmental movement acquired a strong anti-corporate edge. The business community was equally hostile, dismissing environmentalists as people who thought with feelings instead of facts (Dernbach, 2015).

Despite this animosity, the Club of Rome and CEQ both had reputations for thorough and fair analysis, so the business community was more willing to engage with Limits and Global 2000 on their merits. For example, several corporations organized panels and seminars shortly after the publication of Limits featuring speakers who critiqued the report's methodology, but acknowledged the importance of the topic (Dernbach, 2015).

In the decades since the publication of the reports, corporations have come to see environmental protection as a mainstream value. Some of this change in corporate culture is due to the integration of the principles of corporate social and environmental responsibility (CSER) in the curriculums of top business schools (W. H. Meadows, 2015). Today, Harvard Business School and others make CSER courses a mandatory part of their curricula, ensuring future leaders are 
aware of the need to consider social and environmental impacts of their corporate policies (W. H. Meadows, 2015). Limits itself was often used as a textbook in the 1970s, directly influencing the worldviews of generations of business leaders (Dernbach, 2015).

The first generation of CSER-influenced corporate businesspeople is now in power today, and environmentally-minded executives are no longer a fringe minority (Dernbach, 2015). These decisionmakers are more accepting of environmental values than their predecessors, and they are willing and capable of making decisions in the interest of sustainability and environmental quality. An example of such a decision is the tacit acknowledgement by oil companies that many of the oil reserves on their company balance sheets can never be burned (W. H. Meadows, 2015).

\subsection{Driving Substantial Actions}

As described in the following section, neither Limits or Global 2000 were successful in directly inspiring the change their authors desired. Yet, some significant actions did take place due to the reports, mostly in regard to multilateral environmental agreements to which the United States is a party. Although both Limits and Global 2000 were well received internationally, Global 2000 was influential in this respect (Speth, 2016). First, international environmental negotiations came to take a data-driven approach to making the argument for environmental conservation and sustainability following the publication of Global 2000 (Eichbaum, 2015). Moreover, in the decades following the report's publication, nearly every problem described in Global 2000 has become the subject of a major international agreement (Speth, 2016).

This is again thanks in large part to the engagement of WRI, which was deeply involved in supporting the World Commission on Environment and Development (the Brundtland Commission) in the run-up to the 1992 Earth Summit (Speth, 2016). In 1987, the Brundtland Commission released the report, Our Common Future, which provides the most commonly used definition of sustainable development today (Hayes, 2016). Brundtland also likely knew Jørgen Randers, one of the authors of Limits, since Randers was the president of the largest business school in Norway at the time (Eichbaum, 2015).

In terms of domestic policy, the National Environmental Policy Act (NEPA) incorporates explicit consideration of sustainability and environmental concerns into the procedural side of environmental decisionmaking (W. H. Meadows, 2015). Although it passed in 1970, before the publication of Limits, NEPA may be the closest Congress came to a direct response to the problems posed by unsustainable development (Frandsen, 2016; Lash, 2016). In the first few years after NEPA became law, several court decisions, such as Calvert Cliffs Coordinating Committee v. U.S. Atomic Energy Commission (449 F.2d 1109 (D.C.Cir. 1971)) interpreted NEPA to require the government to consider environmental issues at every important stage of the decisionmaking process (Dernbach, 2015). However, two Supreme Court decisions, Vermont Yankee Nuclear Power Corp v. Natural Resources Defense Council (435 U.S. 519 (1978)) and Strycker's Bay Neighborhood Council, Inc. v. Karlen (444 U.S. 223 (1980)) subsequently narrowed the scope of NEPA, reading out the enforceability of the law's substantive requirements for sustainability (Lash, 2016). Nevertheless, NEPA, even in its weakened state, remains one of the most influential environmental statutes in the U.S., cited as the legal basis for nearly all federal environmental actions (Moorman, 2016).

Another procedural consideration that incorporates sustainability is the Pollution Prevention Act (PPA) of 1990. Informed by the Global 2000 report's conclusions on overcrowding, resource use, and other long-term problems, Rep. Howard Wolpe created the PPA with the objective of managing pollution before it is created, rather than repairing the damage of pollution (Frandsen, 2016). By regulating pollution generators, the PPA establishes "source reduction" as a compulsory element of U.S. policymaking.

\section{Factors Hindering the Reports' Influence}

Although Limits and Global 2000 influenced environmental decisionmaking in the U.S. by raising awareness and driving action, neither achieved their principle objective: a profound reorientation of the U.S. and global economies toward long-term sustainability. While most easily perceived issues of local pollution and waste have improved to the point that they are exceptional, the reports were unable to slow the progression of global problems (Eichbaum 2015), leaving the core problem of unsustainable growth unresolved (Dernbach, 2015).

Sustainable development has proven a challenging concept to implement (Dernbach, 2015; W. H. Meadows, 2015). In the U.S., sustainable development remains a niche consideration of economic policy (W. H. Meadows, 2015). Sustainable development remains an "environmental" issue, not a broader "economic" objective. As a result, most economists fail to fully incorporate environmental cost and resource depletion in their work (W. H. Meadows, 2015), and U.S. policymakers have declined to direct development toward sustainability in any meaningful way (Dernbach, 2015). With the exception of occasional small victories, policymakers dismiss proposals to control unsustainable growth time and again in favor of unsustainable, short-term economic development strategies (D. L. Meadows, 2012). 
Several quantitative analyses reveal the extent of this dynamic. In the book, From Resource Scarcity to Ecological Security, Dennis Pirages and Ken Cousins review Global 2000's projections and find that, on the whole, the report's model tracks well to the current day (Pirages \& Cousins, 2005). This finding echoes the conclusions of a review of the projections made in Limits (G. Turner, 2014, p. 18). While the authors of the reports can take pride in the accuracy of their models, the projections that best fit the data assume "business-as-usual" economic growth. The projections' accuracy underscores the extent to which Limits and Global 2000 failed to "move the needle" and catalyze a public policy commitment for effective governance of human society (Eichbaum, 2015; Speth, 2016). Moreover, not only are the limits to growth a crucial underlying cause of famine, conflict, and many other issues confronting society today, but "they are not recognized as such and probably never will be" (D. L. Meadows, 2012). Decisionmakers have ignored the reports' insights, leading society into the dangerous situation of which they were warned. The following sections explore the key reasons why the report's failed to make their desired impact.

\subsection{Confusion and Skepticism}

The persuasive power of Limits and Global 2000 was largely limited to people predisposed to accept its conclusions (Hayes, 2016). Since the reports simply assumed the existence of limits to growth (D. L. Meadows, 2012), people who did not want to hear unrestrained growth could be problematic had the option of simply rejecting the reports' premise (Moorman, 2016). Deploying vague terms like "politicized science" ("Investing in America's Future Act of 2002," 2002, p. H3201), skeptics shaped public dialogue into an argument about beliefs, rather than a fact-based debate about action (Moorman, 2016). The success of this tactic is clear, since the very concept of physical limits to growth is still contested today (G. Turner, 2014, p. 16).

Several sources pointed to the important role played by vested interests-people whose short-term interests were at odds with the conclusions of Limits and Global 2000-in cultivating skepticism about the existence of limits to growth. With great quantities of information available today, people look to certain public commentators to make the flow of information understandable (W. H. Meadows, 2015). Although public figures have provided some criticism of Limits and Global 2000 (Will, 2012), certain organizations, loath to incur the cost and risk of reorienting their business models towards sustainable development, have amplified the voice of lower-profile skeptics to influence public dialogue, much in the same way Exxon funded climate change deniers (Hasemyer \& Cushman Jr., 2015; Moorman, 2016). This belief-based skepticism comes from three principle sources: mischaracterization of the reports' findings, the ideology of techno-optimism, and popular mistrust of science.

\subsubsection{Projecting vs. Predicting}

Much of the criticism directed at Limits and Global 2000 is due to confusion over the actual contents of the reports. Perhaps the greatest contributor to this misunderstanding is the perception that the reports made predictions and not projections. (Note 1) While both reports did project possible future scenarios, neither attempted to calculate the likelihood of a particular scenario. To the contrary, as discussed in section 3.1, the authors took pains to describe how their projections were only valid if technical, social, and cultural policies remained as they were (D. L. Meadows 2012).

However, since "public discourse has difficulty with subtle, conditional messages," the authors of the reports failed to communicate the conditional nature of their results effectively (D. L. Meadows 2012). This led to confusion about whether the reports' conclusions were based on projections or predictions (see, e.g., "Investing in America's Future Act of 2002,” 2002, p. H3201; Nørgård et al., 2010; Will, 2012). This uncertainty was compounded when the biologist Paul Ehrlich used Limits' projections to make short-term predictions about the prices of certain natural resources. When these failed to come true, the reputations of the authors of Limits suffered collateral damage (Dernbach, 2015). Today, despite the authors' attempts to argue otherwise, the popular perception of Limits and Global 2000 is that they "predict[ed] world collapse by the end of the $20^{\text {th }}$ century," and, since did not happen, the reports must have been fundamentally flawed (Turner 2014, 9).

\subsubsection{Techno-Optimism and Mistrust of Science}

Techno-optimism, the belief that human adaptation can overcome all physical limits, provided another source of criticism of the reports (Nørgård et al., 2010). Ronald Reagan gave voice to this perspective in his Second Inaugural Address, arguing, "there are no limits to growth and human progress when men and women are free to follow their dreams."

The argument for human ingenuity and the capacity to substitute has also attracted considerable support within the environmental community (Lash, 2016). While many environmentalists feel physical limits to growth exist as a serious and relevant issue (Eichbaum, 2015), others believe the real focus should be on conserving the global life-support systems that, in the event of their collapse, would have consequences that go beyond the human capacity to adapt (Lash, 2016). Today, the latter argument is dominant within the environmental community. As such, Limits and Global 2000 
are not rejected, but characterized as, "the wrong way to perceive what was happening in the world," and thus irrelevant (Lash, 2016).

Similar to techno-optimism, incompatible religious beliefs, particularly those that reject the validity of scientific techniques as a means of discovering how the world works, provided a third source of popular resistance to the ideas in Limits and Global 2000 (Moorman, 2016). This bears noting because, even though anti-science beliefs are held by few decisionmakers, the American public as a whole demonstrates a greater degree of skepticism when considering scientific evidence than people in most developed countries (World Values Survey Association, 2015). This skepticism diminished the persuasive power of the reports simply because they relied upon scientific reason and observation.

\subsection{The Reagan Administration}

Beyond arguments over the existence of limits to growth, Global 2000 suffered from inopportune political timing. Due to the delays described in Section 3.2, the report came out in the last year of President Carter's term. Although the President engaged publicly with the report and supported its conclusions (Speth, 2014, pp. 138-139), he did not have time to take substantive action to address the findings of Global 2000 in the few months remaining in his term (Barney, 2002, p. 125).

More importantly, Global 2000 became identified with Carter and the Democratic Party as a whole (Hayes, 2016). During his 1980 election campaign, Reagan declined to describe how he would respond to Global 2000's projections and undermined the original rationale for the project, saying, "Well, the response [to Global 2000] must take into consideration what we can do to predict in the long term. I don't think anyone could... [Projections] cannot foresee what is going to happen, what is going to come in the line of technology and so forth" (Associated Press, 1980).

Despite hopes otherwise (see, e.g., Oakes, 1981), the Reagan Administration proved a hostile environment for acting on Global 2000's warnings (Speth, 2016). Instead, "the Reagan Administration tried to shred [figuratively] as many copies of the report as possible" (Lash, 2016). A few politicians continued to push for sustainable development, but most set the topic aside, fearful of comparisons to the unpopular Carter (W. H. Meadows, 2015). Only two years after leaving office, Carter accused Reagan of "a deliberate, across-the-board abandonment of United States leadership on environmental, resource, and related global issues" (Shabecoff, 1983), but his criticism fell upon deaf ears.

Reagan's small government ideology did accommodate environmental protection at the local level (Hayes, 2016), as well as limited federal government interventions to address acute, local-level environmental problems like hazardous waste (Frandsen, 2016). But local governments are not well positioned to address broad cross-jurisdictional environmental problems, since regulatory leakage forces decisionmakers to choose between jobs and environmental quality (Hayes, 2016).

In one of the few official responses to Global 2000, the Reagan Administration clearly distanced itself from the report's premise and conclusions:

"In commenting on the Global 2000 report, this Administration in 1981 disagreed with its call for governmental supervision and control ... the Administration places a priority upon technological advance and economic expansion, which hold out the hope of prosperity and stability of a rapidly changing world. That hope can be realized, of course, only to the extent that government's response to problems, whether economic or ecological, respects and enhances individual freedom" (The United States of America, 1984, p. 3).

\subsection{The Challenge of Adopting a Systemic and Long-Term Approach in the U.S. Political Economy}

Beyond the technical difficulty of understanding the report and the circumstantial obstacle of the Reagan Administration, the U.S. political economy poses a systemic barrier to taking broad, comprehensive action on sustainable development. The U.S. political system discourages holistic thinking by making it difficult for individual decisionmakers, even presidents, to accumulate sufficient political capital; it discourages long-term investments with upfront costs by having frequent elections; and, given the prior two challenges, decisionmakers are unlikely to use precious resources to avoid future disasters so long as there is a chance they might not occur anyway.

Political capital is particularly difficult to accumulate in regard to environmental law and policy. Responsibility for environmental issues is distributed among different congressional committees, so acting on a crosscutting environmental issue might require the support of four or five congressional committees (Frandsen, 2016). Aligning multiple interests requires many compromises, so "today's environmentalism tends to be pragmatic and incrementalist" (Speth, 2014, pp. 151-152). Motivated by the need to succeed within the existing political system, ambitious reforms are watered down through compromise and negotiation (Frandsen, 2016). While this strategy has led to some important victories, it "locked us into patterns of environmental action that have since proved no match for the system we're up against" because such a piecemeal approach is "closely allied to a tendency to deal with effects rather than underlying 
causes" (Speth, 2014, pp. 151-152).

Time is also a limiting factor. The drive for sustainable development is a major undertaking that requires decisionmakers to opt for changes with steep upfront costs and delayed benefits (D. L. Meadows, 2012). With elections every two, four, or six years, the next evaluation will come long before politicians can take credit for their actions. Aware of the public's short-term perspective (Randers, 2012) and under pressure to use their limited political capital on issues voters care about, politicians are generally unwilling to spend resources on the long-term problems of resource depletion and sustainability (W. H. Meadows, 2015; Randers, 2012). Limits and Global 2000 may have even had a perverse effect on lawmakers by revealing the scale and duration of effort it would take to achieve sustainable development (Eichbaum, 2015).

Policymakers are also reluctant to commit whatever resources they have managed to accumulate toward addressing future problems, largely due to the uncertainty inherent to far-reaching, complex forecasts. From the Limits and Global 2000 models, it is clear that "we will reach the physical limits to growth on this planet soon. What does soon mean? That is not something you can tell from our models" (D. L. Meadows, 2012). Uncertainty, in regards to timing, magnitude, or any other factor, breeds doubt and dissent, which weaken the analysis' capacity to inspire change.

With the political system geared for narrow and specific action, decisionmakers tend to focus on relatively straightforward questions of policymaking, permitting, and adopting standards; discrete problems they can solve with their limited political capital and use in their re-election campaigns (Dernbach, 2015). In the meantime, the dispersal of political capital, short-term thinking, and uncertainty of projecting the future predisposes to inaction, so long-term, systemic threats remain unaddressed (Frandsen, 2016) and "we are stuck in a system... where politics and the market systematically drive us over the cliff” (D. L. Meadows, 2012).

Some of those interviewed even suggest that, given the difficulty democratic systems demonstrate in establishing conditions favorable to long-term, systems-level decisionmaking (Eichbaum, 2015), a technocratic approach may be better suited to achieving sustainable development (Moorman, 2016).

\subsection{Desire to pursue unrestrained growth}

Finally, there is a fundamental incompatibility between the core message of Limits and Global 2000, that economic growth comes with costs that will only continue to rise, and the "unquestioning society-wide commitment to economic growth at any cost" currently present in the United States (Speth, 2014, p. 153). Given the American public's implicit respect for a "corporate right to profit" (Eichbaum, 2015), there is little appetite to impose controls of any kind on economic growth, even if "an ever-growing economy" will "undermin[e] the ability of the planet to sustain human and natural communities" (Speth, 2014, pp. 153-154). In August 2010, Jeffery R. Immelt, CEO of General Electric, summarized this objection, saying, "We know the solution. But we don't like it" (Randers, 2012).

Moreover, forthright acknowledgement of the limits to growth would conflict with the public's desire to improve living standards for the less fortunate without giving up what Americans already enjoy. What so unnerved people about Limits and Global 2000 was not the prospect of overshoot and collapse, but "the fear that we all have now of looking in the eye of a person from Bangladesh, or Malawi, or Czechia, or Ghania [sic]" and saying, "If [you] tried to live as well as [we] do, it would destroy Earth (Barney, 2002, p. 128)." When Global 2000 was being prepared, the idea of such an uncomfortable conversation motivated "a relatively senior government official" to say to the lead author, Gerald O. Barney, "Global 2000 cannot suggest that developing countries face challenges any more difficult than those faced by the United States" (Barney, 2002, p. 128). It may have been "the moral challenge" of the conclusion, "the challenge to developing countries is greater than the challenge to the United States" that sapped the persuasive power of Limits and Global 2000 (Barney, 2002, p. 128).

When confronted with evidence that continued unsustainable growth would lead to major problems, most decisionmakers have found it easier to deny or ignore the need to take decisive action. However, the persistent incompatibility between the public's desire for a resource-intensive lifestyle for all and environmental reality does oblige the advocates for "business-as-usual" growth to create one rationale after another, retreating each time their position became untenable relative to environmental reality (D. L. Meadows, 2012). By denying the ongoing conflict among economic growth, social equity, and ecological limits, decisionmakers not only dismiss the practical relevance of planetary boundaries, but also defend the pursuit of unrestrained growth (Gómez-Baggethun \& Naredo, 2015, p. 393).

\section{Discussion and Conclusion}

This analysis has at least two limitations. First, since the interviews were semi-structured, interviewees were free to respond to the same questions in different ways. Consequently, some aspects of this analysis rely on the perspective of fewer interviewees than others. However, all interviews covered the same broad topics and the literature review provides additional support to sections that were not discussed in multiple interviews. Second, interviewees sometimes 
presented assertions that are impossible to verify independently. Although outside sources were used to support these statements when appropriate, content from the interviews should be regarded as informed opinions rather than statements of fact.

Despite these shortcomings, the interviewees represent a well-balanced group of people who were and often remain thought leaders in the field of environmental governance. With the additional support of primary and secondary sources, this study presents a robust, nuanced viewpoint on how decisionmakers perceive Limits and Global 2000, in terms of both the reports' influence on past environmental decisionmaking and their potential to do so in the future.

We concluded that Limits and Global 2000 had an unmistakable influence on environmental governance in the U.S. The reports' most important concept, the need for sustainable development, has become the principal frame through which the environmental profession understands environmental problems (Dernbach, 2015), inherent in the consideration of almost every environmental issue (Eichbaum, 2015). The environmental movement has used the reports as a foundation, with Limits a fixture on the bookshelves of many decisionmakers over the decades (Eichbaum, 2015). Today, sustainable development is the core priority for WRI and several other major environmental institutes (Speth, 2016), which pose the reports' questions with greater specificity and work with decisionmakers to make change happen on the ground (Dernbach, 2015; Moorman, 2016). Over the past 40 years, environmental thinkers have "never really lost the thread" of the reports (Dernbach, 2015), more and more resources are directed toward solving the problem of unsustainable development, and the "steady drumbeat of sustainability" has grown ever louder (W. H. Meadows, 2015).

Yet, Limits and Global 2000 also failed. Ultimately, the reports sought to catalyze a fundamental shift in the development of the world economy. But the reports were rebuffed by hostile political agendas, frustrated by incompatible policymaking tools, and subsumed by the unstoppable drive for short-term economic growth. Due to a combination of confusion, mistrust, and outright rejection, decisionmakers today perceive Limits and Global 2000 to be "largely wrong" (Lash, 2016). Unable to inspire movement toward sustainable development at sufficient scale, the reports did not achieve their goals.

Indifferent to "doomsday cries," the world has carried on much as before (G. Turner, 2014, p. 18). Society has already pushed several global life-support systems beyond their limits (Steffen et al., 2015, fig. 3), and "The global system is now far above its carrying capacity" (D. L. Meadows, 2012). If Limits' business-as-usual projections continue to hold true, as they have for the past 40 years, the world will enter the early stages of global collapse between 2015 and 2025 (G. Turner, 2014, p. 16).

Despite the passage of four decades, it is still too soon to determine the full impact of Limits and Global 2000. So long as the global life-support system has not passed its tipping point toward collapse, a sustainable society will remain possible. If the U.S. ever realizes such a society, the reports will have played an important role in its development. If not, there will be bigger things to worry about.

\section{Acknowledgements}

This work was supported by JSPS KAKENHI Grant Number JP26550114. We express heartfelt appreciation to the interviewees for their cooperation. We also express our sincere gratitude to Elissa Parker, Carl Bruch, and Linda Breggin of the Environmental Law Institute for their support to compile an initial list of potential interviewees according to relevant knowledge and experience.

\section{References}

Associated Press. (1980, October 15). Transcript of Ronald Reagan's remarks at news conference in Los Angeles. The New York Times, 24.

Barney, G. O. (Ed.). (1980). The global 2000 report to the President: entering the twenty-first century (Vol. 1). Washington, D.C.: US Government Printing Office.

Barney, G. O. (2002). The global 2000 report to the President and the Threshold 21 model: influences of Dana Meadows and system dynamics. System Dynamics Review, 18(2), 123-136. http://doi.org/10.1002/sdr.233

Carter, J. (1977, May 23). The environmental message to the Congress. The American Presidency Project. Retrieved from http://www.presidency.ucsb.edu/ws/?pid=7561

Dernbach, J. (2015, December 16). [In-person].

Eichbaum, B. (2015, December 7). [In-person].

Frandsen, R. "Dick.” (2016, January 19). [In-person].

Gómez-Baggethun, E., \& Naredo, J. M. (2015). In search of lost time: the rise and fall of limits to growth in international sustainability policy. Sustainability $\quad$ Science, $10(3), \quad 385-395$. 
http://doi.org/10.1007/s11625-015-0308-6

Hasemyer, D., \& Cushman Jr., J. H. (2015, October 22). Exxon sowed doubt about climate science for decades by stressing uncertainty [News Website]. Retrieved http://insideclimatenews.org/news/22102015/Exxon-Sowed-Doubt-about-Climate-Science-for-Decades-by-Stressi ng-Uncertainty

Hayes, D. (2016, January 25). [In-person].

Investing in America's future act of 2002. (2002). Congressional Record Online, 148(72), H3182-H3203.

Kress, W. J. (Speaker) (2012, March 1). Introductory remarks [Speech]. Perspectives on limits to growth: challenges to building a sustainable planet, Smithsonian Institution, Washington, D.C. Retrieved from https://www.youtube.com/watch?v=ZiG3I5DaPrE\&list=PL2817969CA87E5B47

Lash, J. (2016, January 12). [In-person].

Lewis, A. (1972, June 19). Growth and politics. The New York Times, 33.

MacCracken, M. (2001, February). Prediction versus projection - forecast versus possibility. WeatherZine, (26). Retrieved from http://sciencepolicy.colorado.edu/zine/archives/1-29/26/guest.html

Mavroules, N. A joint resolution calling on the Executive Branch to conform to the recommendations of the Global 2000 report., $\quad$ H. $\quad$ J. Res.248 (1983). Retrieved from https://www.congress.gov/bill/98th-congress/house-joint-resolution/248

Meadows, D. H., Meadows, D. L., Randers, J., \& Behrens III, W. W. (1972). The limits to growth (1st ed.). New York: Universe Books.

Meadows, D. L. (2012, March 1). It is too late for sustainable development [Speech]. Perspectives on limits to growth: challenges to building a sustainable planet, Smithsonian Institution, Washington, D.C. Retrieved from https://www.youtube.com/watch?v=f2oyU0RusiA\&index=5\&list=PL2817969CA87E5B47

Meadows, W. H. (2015, December 4). [In-person].

Moorman, J. (2016, January 22). [In-person].

Nørgård, J. S., Peet, J., \& Ragnarsdóttir, K. V. (2010). The history of the limits to growth. Solutions, 1(2), 59-63.

Oakes, J. B. (1981, January 20). For Reagan, a ticking ecological "time bomb." The New York Times, p. 31.

Pirages, D., \& Cousins, K. (Eds.). (2005). From resource scarcity to ecological security: exploring new limits to growth. Cambridge, Mass: The MIT Press.

Randers, J. (2012, March 1). Lessons from forty years of promoting the limits to growth [Speech]. Perspectives on growth: challenges to building a sustainable planet, Smithsonian Institution, Washington, D.C. Retrieved from https://www.youtube.com/watch?v=ILrPmT6NP4I\&list=PL2817969CA87E5B47\&index=6

Reinhold, R. (1972, February 27). Mankind warned of perils in growth. The New York Times, pp. 1, 40.

Shabecoff, P. (1983, June 3). Reagan environment policy sharply attacked by Carter. The New York Times, p. 18.

Silk, L. (1972, March 13). Questions must be raised about the imminence of the disaster'. The New York Times, p. 35.

Speth, J. G. (2014). Angels by the river: a memoir of sorts. White River Junction, Vermont: Chelsea Green Publishing.

Speth, J. G. (2016, January 20). [In-person].

Steffen, W., Richardson, K., Rockstrom, J., Cornell, S. E., Fetzer, I., Bennett, E. M., ... Sorlin, S. (2015). Planetary boundaries: guiding human development on a changing planet. Science, 347(6223), 1259855-1259855. http://doi.org/10.1126/science.1259855

The United States of America. (1984, August 13-16). Policy statement of the United States of America at the United Nations International Conference on Population. Mexico, D.F. Retrieved from http://abortion.procon.org/sourcefiles/MexicoCityPolicy1984.pdf

Turner, G. (2014). Is global collapse imminent? (MSSI Research Papers No. 4). Melbourne, Australia: Melbourne Sustainable Society Institute, The University of Melbourne. Retrieved from http://sustainable.unimelb.edu.au/sites/default/files/docs/MSSI-ResearchPaper-4_Turner_2014.pdf

Turner, G. M. (2008). A comparison of The Limits to Growth with 30 years of reality. Global Environmental Change, 18(3), 397-411. http://doi.org/10.1016/j.gloenvcha.2008.05.001

Will, G. F. (2012, August 17). Why doom has not materialized. The Washington Post. Retrieved from 
http://www.washingtonpost.com/opinions/george-will-why-doom-has-not-materialized/2012/08/17/fcf89ed6-e7fb11e1-936a-b801f1abab19_story.html

World Values Survey Association. (2015, April 18). World Values Survey 1981-2014 Longitudinal Aggregate .20150418. JDSystems. Retrieved from http://www.worldvaluessurvey.org/WVSContents.jsp

\section{Note}

Note 1. A prediction is a statement of the probable ("X will happen") and a projection is a statement of the possible ("If Y, then X will happen"). For a more detailed explanation, see (MacCracken, 2001).

\section{(cc) BY}

This work is licensed under a Creative Commons Attribution 3.0 License. 